\title{
"EFEITO DE REAL" VERSUS SOBRENATURAL: UM CONFLITO NECESSÁRIO À CONSTRUÇÃO DA FANTASTICIDADE EM ESFINGE, DE COELHO NETO
}

\author{
Andressa Silva Sousa ${ }^{1}$ \\ Emanoel Cesar Pires de Assis ${ }^{2}$
}

\begin{abstract}
Resumo: A partir da noção de efeito de real, marca, segundo Roland Barthes (1971), essencial para os textos realistas, busca-se compreender como a narrativa Esfinge, do escritor caxiense Coelho Neto, utiliza estratégias de descrições do mundo extratextual para, aos poucos inserindo fatos sobrenaturais, construir o que pode se chamar de fantasticidade da obra. Assim, defendemos que a construção do fantástico na obra em análise está atrelada à forma como a narrativa utiliza as referências do mundo real e como elas, por se oporem aos fatos fantásticos da obra, impõem no leitor a solução de uma dúvida. A pesquisa segue os direcionamentos teóricos de Tzvetan Todorov (1975), Antonio Compagnon (2010), David Roas (2014) e Irlemar Chiampi (2015).
\end{abstract}

Palavras-chave: Literatura Fantástica. Efeito de Realidade. Sobrenatural. Coelho Neto

\section{INTRODUÇÃO}

Desde sua origem, em meados dos séculos XVIII e XIX, até seu amadurecimento, no século XX, a literatura denominada fantástica recebeu muitos conceitos. Recaem suas formas, não existe um conjunto de características fixas capazes de traduzi-la em sua totalidade. No entanto, é verificável a existência de traços comuns entre os textos ditos fantásticos e, com tais atributos, é possível construir um esboço que a represente.

Atualmente, são várias as teorias que apontam novas perspectivas de análises desse gênero literário, concordando entre si ou divergindo em determinados pontos. Longe de ser prejudicial, a diversidade de teorias clássicas e contemporâneas sobre o Fantástico proporciona uma visão mais globalizante sobre o gênero e revela também que, por sua metamorfose contínua, a literatura fantástica se mantém atualizada e, por isso, sempre misteriosa e sedutora.

$O$ presente artigo discorre sobre o que Roland Barthes denominou "efeito de real", marca de que se assenhoraram os textos literários

\footnotetext{
${ }^{1}$ Mestranda em Letras no Programa de Pós-Graduação em Letras da Universidade Estadual do Maranhão - UEMA. E-mail: andysousa.jc@hotmail.com

2 Doutor em Literatura na Universidade Federal de Santa Catarina (UFSC). Professor do Departamento de Letras da Universidade Estadual do Maranhão - UEMA/Campus Caxias. E-mail: emanoel.uema@gmail.com
} 
realistas, mas que é imprescindível também à construção da narrativa fantástica; - que causa estranhamento à primeira vista, uma vez que por tratar de acontecimentos sobrenaturais, imagina-se que a literatura fantástica não estabeleça relação alguma com a realidade. $O$ objeto de análise escolhido foi a obra Esfinge, romance fantástico da literatura brasileira, do escritor Coelho Neto, tendo como base, entre outros teóricos, os estudos de Tzvetan Todorov (1975), Antoine Compagnon (2010), David Roas (2014) e Irlemar Chiampi (2015).

\section{O "Efeito de real" e sua importância para a Literatura Fantástica}

Que relação existe entre a obra literária e o mundo real? A simplicidade do questionamento esconde a complexidade das discussões que se ergueram ao longo dos séculos no intuito de respondê-lo. De acordo com Compagnon (2010), desde a Poética de Aristóteles, a mimesis é o termo mais corrente sobre o qual se sustentaram as relações entre literatura e realidade. A palavra grega foi traduzida de muitas formas, modificando-se de uma teoria para outra, mas sem nunca resolver o problema. Entre as traduções mais comuns estão: "imitação", "representação", "verossimilhança", "ilusão", "mentira", além de "realismo", "referente", "referência" e "descrição". Nesse sentido, a literatura seria uma forma de imitação, uma cópia do mundo real.

Inquestionado por muito tempo, o termo aristotélico foi então sacudido pelo surgimento da "doutrina da autorreferencialidade do texto literário, isto é, a ideia de que 'o poema fala do poema' e ponto final" (COMPAGNON, 2010, p. 95), a partir desse momento, defendeu-se a independência da literatura sobre a realidade. A impossibilidade de a literatura fazer referência ao mundo empírico explica-se, segundo a teoria dos signos de Peirce, pela inexistência de uma ligação direta entre o signo e o objeto. Tudo o que se pode dizer da realidade, não é a realidade em si, mas uma ideia, um discurso sobre ela, pois "a coisa em si independe de suas propriedades" (CHIAMPI, 2015, p. 91). Assim,

(...) o referente não existe fora da linguagem, mas é produzido pela significação, pela interpretação. O mundo sempre é já interpretado, pois a relação linguística primária ocorreu entre representações, não entre a 
palavra e a coisa, nem entre o texto e o mundo. (COMPAGNON, 2010, p. 97).

Diante das teorias postas, qual delas escolher: a literatura fala de si mesma ou a literatura fala do mundo? Mais questionamentos. Se se o mundo empírico não é ele mesmo, pois tudo o que há nele são representações dadas e, por isso,não é possível referenciá-lo; se a literatura não pode copiar o real, como se explica o fato de, em face do texto literário, pensar-se exatamente o oposto?; ou seja, "como ele nos faz pensar que copia o real?" (COMPAGNON, 2010, p. 107).A resposta é: por meio do "efeito de real"- processo em que a literatura dissimula fazer referência à exterioridade.

A fim de que o "efeito de real" se estabeleça na narrativa literária, seja ela fantástica ou não, é fundamental que ocorra, primeiramente, um acordo entre leitor e narrador. Conforme David Roas (2014), como toda ficção quer-se crível, o leitor deve aceitar tudo o que o narrador conta sem questionar; realizar o pacto ficcional, ou seja, acordar "uma suspensão voluntária das regras de verificação" (p. 51). Ler a obra sem buscar a comprovação histórica dos fatos narrados. Ler sem "pôr em xeque" o estatuto fantasioso da obra.

Com relação à literatura fantástica, a necessidade do pacto ficcional é ainda maior, uma vez que, em uma perspectiva etimológica, o termo fantástico " (do latim phantasticu, por sua vez do grego phantastikós, os dois oriundos de phantasia)"(RODRIGUES, 1988, p. 9) influencia o leitor, de antemão, a envolver toda a obra sob o manto da incredulidade; deixando mais explícita a condição da obra como fruto da imaginação e de seu afastamento da realidade extralinguística. Por isso, Roas (2014) considera legítimo "acabar com a ideia comum de situar o fantástico no terreno do ilógico e do onírico, ou seja, o oposto da literatura realista" (p.51). Foi exatamente isso que se buscou no século XX, período de amadurecimento da literatura fantástica.

De acordo com Theodor Adorno, em meados do século XX, o realismo era imanente ao romance e "até mesmo os romances que, devido ao assunto, eram considerados 'fantásticos', tratavam de apresentar seu conteúdo de maneira a provocar a sugestão do real" (ADORNO, 2003, p. 55). Mesmo os teóricos que não consideram a "ilusão do real" o elemento essencial da literatura fantástica 
concordam que esta noção se faz presente em tal gênero. Entre eles está o búlgaro Tzvetan Todorov.

Em sua obra Introdução à Literatura Fantástica (1975), Todorov apresenta a hesitação como a característica definidora da literatura fantástica. Esta se revela quando o leitor ou as personagens da narrativa, em face de um acontecimento aparentemente sobrenatural, enfrentam uma luta psicológica na tentativa de descobrir se o que presenciaram de fato aconteceu ou se tudo não passou de uma ilusão dos sentidos. O conflito se estabelece porque 0 acontecimento sobrenatural é de uma natureza oposta ao ambiente em que ele é introduzido:

\begin{abstract}
Somos assim levados ao âmago do fantástico. Num mundo que é exatamente o nosso, aquele que conhecemos, sem diabos, sílfides nem vampiros, produz-se um acontecimento que não pode ser explicado pelas leis deste mundo familiar (TODOROV, 1975, p. 30-grifos nossos).
\end{abstract}

Desse modo, o espaço diegético de uma obra fantástica apresenta-se semelhante ao do mundo extratextual. Um mundo regido pelas leis fixas da natureza, capazes de trazer ao leitor uma segurança de que nada fora do comum surgirá neste ambiente, para então inserir neste espaço o sobrenatural. Neste momento, faz-se necessário expor que o sobrenatural existe apenas em oposição ao que é natural, ao que julgamos real, pois quando se adjetiva algo como "estranho", existe um padrão preestabelecido socialmente do que seja o "normal", pois a própria noção de realidade inclui:

(...) o bom senso, a convenção social, de modo que, ao lado do que é válido cientificamente para todas as épocas e imutável em sentido transhistórico e transcultural, há o "natural" histórico, o qual é mutável e enquadrado em certo tempo e espaço (CHIAMPI, 2015, p. 54).

A concepção do fantástico a partir da ideia de realidade depende do contexto sociocultural, pois a noção do que é real ou não para uma população, se faz por meio da cultura, da arte, das crenças, dos costumes e das relações sociais deste mesmo povo. O leitor extrai ou elabora seu conceito de realidade a partir dos contextos social, cultural e econômico em que ele está inserido. O que é possível ou não para determinada sociedade se definir por meio desses 
componentes. Portanto, "a Literatura Fantástica fica fora do que é aceito socioculturalmente" (ROAS, 2014, p. 47), pois ela diverge desses padrões estabelecidos de normalidade. A realidade extratextual é o paradigma. Será sobrenatural tudo o que se desviar dela.

Antes de Tzvetan Todorov, H.P.Lovecraft, escritor e estudioso de literatura de temática sobrenatural, também escreveu acerca da construção da diegese fantástica. Em sua obra O Horror Sobrenatural em Literatura, o autor deixa claro que o rompimento das leis fixas da natureza, que são inseridas na diegese pela ilusão referencial, precisa estar explícito no texto:

\begin{abstract}
Uma certa atmosfera inexplicável e empolgante de pavor de forças externas desconhecidas precisa estar presente; e deve haver um indício, expresso com seriedade e dignidade condizentes com o tema, daquela mais terrível concepção do cérebro humano - uma suspensão ou derrota maligna e particular daquelas leis fixas da Natureza que são a nossa única salvaguarda contra os assaltos do caos e dos demônios dos espaços insondáveis (LOVECRAFT, 2007, p. 17- grifo nosso).
\end{abstract}

Pelo que foi dito na citação acima, entende-se que, para Lovecraft, a verdadeira Literatura Fantástica se faz num contexto muito específico. A narrativa deve apresentar uma atmosfera de pavor causada pela influência de forças externas de origem desconhecida, além de expressar a ruptura das leis naturais que regem o universo. Estas leis rígidas e inquebráveis proporcionam equilíbrio ao mundo ficcional, “uma espécie de 'sistema estável' do leitor, cuja segurança é ameaçada pelos terrores de um sobrenatural que pode-vir-a-ser" (CHIAMPI, 2015, p. 54- grifo do autor). Quando, porém, ocorre esse rompimento, as crenças do leitor são abaladas. Com essa "derrota maligna", vem a forte sensação de insegurança e fragilidade diante dos horrores que, outrora, eram inconcebíveis.

Por esta razão, o sobrenatural na teoria roasiana é entendido como o elemento desestabilizador, "ele vai supor sempre uma ameaça à nossa realidade" (ROAS, 2014, p. 31). Ele chega de forma abrupta, inesperada e abala os alicerces do mundo real. Assim como Roas, teóricos como Castex, Louis Vax e Roger Caillois ao definirem o fantástico, parecem entendê-lo do mesmo modo:

1.“O fantástico ... se caracteriza... por uma intromissão brutal do mistério no quadro da vida real" 2. "A narrativa fantástica ... gosta de nos 
apresentar, habitando o mundo real em que nos achamos, homens como nós, colocados subitamente em presença do inexplicável".3. "Todo fantástico é a ruptura da ordem estabelecida, irrupção do inadmissível no seio da inalterável legalidade cotidiana" (apud TODOROV, 1975, p. 32).

A definição de Vax (a de número 2) enfatiza que essa vida real representada na obra se desenvolve de maneira semelhante à nossa. Este recurso de que se utilizam os autores para conferir veracidade aos seus textos, apoiados na semelhança deste com o mundo real, é a verossimilhança. Como diz Rodrigues (1988, p.19) "um texto verossímil (vero- símil: semelhante à verdade), seria aquele que convence o leitor por sua fidelidade à natureza". Assim como nos estudos de Todorov, o leitor se torna importante porque é ele quem questiona a natureza do fenômeno sobrenatural, instaurando a dúvida. Neste contexto, também é ele quem procurará na história narrada sua semelhança com a realidade empírica, percebendo o que há de incomum e estranho nela.

Castex, por sua vez, usa a expressão "intromissão brutal" para reforçar a maneira violenta como o mistério se adentra na vida real. Essa violência, nas palavras de Caillois, provoca o rompimento de leis até então inalteráveis, responsáveis pela ordem cotidiana. Por esse motivo, o sobrenatural, fenômeno desestabilizador da ordem natural dos acontecimentos, imprime no leitor um sentimento de dúvida em relação ao seu próprio mundo. Esta dúvida distingue-se, pois, da hesitação todoroviana:

\begin{abstract}
Baseada, portanto, na confrontação do sobrenatural e do real dentro de um mundo ordenado e estável como pretende ser o nosso, a narrativa fantástica provoca - e, portanto, reflete - a incerteza na percepção da realidade e do próprio eu; a existência do impossível, de uma realidade diferente da nossa, leva-nos, por um lado, a duvidar desta última e causa, por outro, em direta relação com isso, a dúvida sobre nossa própria existência (ROAS, 2014, p. 32).
\end{abstract}

Ao reconhecer a existência de fatos extraordinários como pertencentes à realidade, é impossível permanecer incólume. Se o que foi considerado impossível tornou-se realidade, nada impede a contestação da veracidade do que é aceito como real. Os seres humanos serão deixados à deriva em um mar de incertezas. Ao rejeitar a racionalidade científica como último veredicto para explicar o universo, a literatura fantástica abre os olhos da humanidade a fim de 
que se cogite a existência de outras realidades de condições complexas e incompreensíveis ao conhecimento ainda tão limitado.

Apresentadas tais perspectivas teóricas em que os termos "inexplicável", "mistério", "inadmissível" aparecem aliados aos conceitos de "vida real", "mundo real", "leis fixas da natureza" e "cotidiano", não é difícil perceber a íntima ligação que o sobrenatural tem com a realidade. É uma relação de contraste, de oposição. Se não houvesse esse enfrentamento, ou seja, se os acontecimentos insólitos fossem aceitos facilmente, e não entrassem em conflito com o contexto em que os fatos acontecem, como a noção de realidade, o fantástico não seria produzido. O "efeito de real", portanto, é indispensável à construção da fantasticidade.

\section{A construção do "efeito de real" e a irrupção do sobrenatural no romance} Esfinge, de Coelho Neto

O Fantástico, como todo gênero literário, possui características que lhe são próprias. Tais caracteres, quando bem articulados, imprimem na narrativa 0 que Irlemar Chiampi (2015), Roas (2014) e outros teóricos chamam de fantasticidade. Neste momento, analisaremos um aspecto necessário à construção do efeito fantástico presente no romance Esfinge (1925): a relação conflituosa entre o sobrenatural e o real ficcional.

Segundo Roas (2014), o fantástico

(...) está inscrito permanentemente na realidade, a um só tempo apresentando-se como um atentado a esta mesma realidade que o circunscreve. (...) sabemos que um texto é fantástico por sua relação (conflituosa) com a realidade empírica. Porque o objetivo fundamental da narrativa fantástica é questionar a possibilidade de um rompimento da realidade empírica" (2014, p. 52).

Em tal caso, o primeiro degrau para alcançar a fantasticidade é a reprodução, na obra, da "noção empírica de mundo real" (CHIAMPI, 2015, p. 54). Pois se os acontecimentos estranhos aparecem em um espaço igualmente desordenado e imprevisível, se torna impossível reconhecê-los como sobrenaturais. O espaço precisa ser de uma natureza oposta ao dos 
acontecimentos. Com este objetivo, o narrador lança mão de alguns recursos que reafirmam a referencialidade do espaço textual, criando uma correspondência entre os conteúdos da ficção e a experiência concreta, como "a datação precisa, a descrição minuciosa dos objetos, personagens, espaços" (ROAS, 2014, p. 164).

O mundo ficcional da obra Esfinge, de início, apresenta-se diante do leitor como uma realidade totalmente aceitável, uma vez que o espaço da diegese apresentado pelo narrador possui um padrão de funcionamento semelhante ao do mundo extratextual. Nas linhas iniciais, ele descreve o ambiente mais importante da obra: a pensão Barkley.

\begin{abstract}
A pensão Barkley, na rua Paysandú, tinha a celebridade honesta de um lar de família.

Discreta, sem reclamo algum, nem sequer uma placa no portal de granito, confortavelmente instalada em prédio antigo e vasto, parecia dormir sono de encanto à sombra do arvoredo, no fundo do jardim, onde uma cascatinha de rocalha alegrava o silêncio com leve, perene e fresco murmúrio d'água (NETO, 1925, p. 7).
\end{abstract}

Simples e modesta, era muito bem vista pela comunidade. Antes de ter as chaves de um de seus aposentos, o interessado deveria dar provas de sua boa conduta moral. Tão respeitada era, que "o recibo da 'Pensão Barkley' valia como fiança no comércio e como folha corrida na sociedade" (NETO, 1925, p. 10). É verdade que a maneira como as palavras foram utilizadas na representação do espaço se distancia do que consideramos cotidiano, conferindo-Ihe até um tom poético. Mesmo assim, o lugar não adquiriu formas fantasiosas.

O local é um prédio antigo; está situado em uma rua que tem nome como a maioria; tem árvores ao redor, um jardim e um chafariz. Tais qualidades fazem dela uma pensão diferenciada, mas não extraordinária. É apenas um excelente local de moradia como tantos outros possíveis de se achar. A pensão, além de imaginável dentro dos padrões lógicos, apresenta-se como um lugar aconchegante e seguro, como um lar:

Apesar da vastidão senhorial do prédio eram poucos os que gozavam a sua tranquilidade, o conforto macio das suas poltronas Maple, a alvura cheirosa dos seus linhos, a sua sólida e farta refeição, as flores de seu 
jardim, que nunca faltavam à mesa de jantar, nas étageres, nos aposentos, e sempre frescas (NETO, 1925, p. 10).

Por meio da descrição cuidadosamente detalhada acima, o narrador oferece ao leitor um banquete de experiências sensoriais, influenciando-o a vivenciar, por meio de todos os sentidos, uma imersão mais profunda no espaço da narrativa. A maciez das poltronas, a cor e o cheiro do linho e das flores, bem como o sabor das refeições é um convite para que o leitor comprove, por ele mesmo, que tudo o que é dito sobre a pensão de fato existe, intensificando a "ilusão do real". Isso nos faz relembrar que é exatamente por meio dos órgãos do sentido que se consegue apreender a realidade empírica.

O segundo elemento utilizado pelo narrador homodiegético para conferir confiabilidade ao texto quanto a sua possibilidade do real são as personagens. No início da narrativa, todas elas são cuidadosamente definidas, desde as suas características físicas até seus traços de personalidade; todas têm profissões e ocupações como as que se veem no mundo real. Ao leitor, fica evidente que as personagens são pessoas comuns, não seres sobrenaturais. Miss Barkley, por exemplo, a dona da pensão, é uma mulher trabalhadora e acorda sempre cedo, antes de todos, a fim de dar aos seus hóspedes o máximo de conforto e bem-estar. Com firmeza, ela mantém tudo o que diz respeito à organização do lugar sob seu controle.

Os hóspedes são Frederico Brandt, um "professor de piano, crítico musical e compositor exímio" (NETO, 1925, p. 8) que dorme em um aposento separado dos demais para não incomodar outros moradores como o comendador Bernaz, o morador mais antigo: "Rabugento e caseiro, sempre a esmoer, passava os dias encerrado ou, nos grandes calores, aproveitando as manhãs e as tardes" (NETO, 1925, p. 10); a professora Miss Fanny, mulher batalhadora que passa 0 dia fora da pensão a ensinar crianças. Era "sardenta e sofria de enxaquecas, sempre com o vidrinho de sais e cápsulas no bolso" (NETO, 1925, p. 11-2).

Além dos mencionados, vivem na pensão, Basílio, um guarda-livros, cujo quarto "era o desespero de Miss Barkley, porque o homem fazia questão de o manter em desordem, com os livros espalhados, os jornais, as revistas pelo chão" (NETO, 1925, p. 12) e "três rapazes exemplares" (NETO, 1925, p. 13): Chrispim, um estudante de direito "muito magro, sardento, com o pincenez 
montado no nariz em bico, os cabelos arrepelados" (NETO, 1925, p. 37-8) e os irmãos Carlos e Eduardo que trabalhavam numa importadora.

Por fim, os últimos inquilinos: o narrador-personagem e o inglês James Marian. Nada é dito sobre o primeiro, nem mesmo o nome. Quanto ao segundo, suas características mais marcantes são o comportamento antissocial e a aparência exótica: “(...) sempre sorumbático, calado, aparecendo raramente à mesa às horas das refeições, tomando-as só ou no quarto (...) Era um formoso mancebo, alto e forte" (NETO, 1925, p. 13). No entanto, contrastando com o porte masculino, "era o rosto de feminina e suave beleza" (NETO, 1925, p. 14).

Apesar dos traços físicos e do comportamento incomuns, o narrador desvia a atenção do leitor de possíveis desconfianças, apresentando o lado social de James, aproximando-o novamente dos outros homens. Aos domingos, como de costume, ele se dedicava à prática de esportes: "Aos domingos, cedo, todo de branco, saia com a raquete para o tênis ou com a bolsa em que levava a roupa para o futebol" (NETO, 1925, p. 13).

Diante da breve exposição das personagens, é perceptível que todas compartilham dos mesmos atributos que definem a raça humana, até mesmo James Marian. Diante do leitor, desfilam pessoas trabalhadoras, tímidas, desorganizadas, alegres, sérias, belas, estudiosas entre outras. Nesse sentido, além do ambiente mostrar-se seguro e previsível, seus habitantes também são seres que se demonstram confiáveis e reais. Por tais qualidades serem facilmente encontradas em alguém; observando-as, o próprio leitor se enxerga nelas, incluindo-se assim no enredo.

Em Esfinge, Coelho Neto atinge o que o teórico espanhol conceitua como a "duplicação do âmbito cotidiano em que o receptor se move", transferindo "o mundo real ao texto em sua mais absoluta cotidianidade" (ROAS, 2014, p. 1645):

Voos de pássaros e de borboletas anunciaram a madrugada e o sol, ainda frio, lançou as primeiras púrpuras [...]

Debrucei-me à janela. $O$ jardineiro, sentado à borda de um canteiro, esfiava amarrilhos para as plantas e a rua, em burburinho, acordava com o rumor dos veículos. Tiniam campainhas, soavam trombetas e as folhas inquietas das palmeiras altas lampejavam douradas pelo sol.

Alfredo, em baixo, arremangado e descalço, atirava baldes d'agua à varanda, e à janela do seu aposento, esgargalado, com os cabelos em 
gaforinha, Basílio pigarreava rascando a guela pegajosa (NETO, 1925, p. 60-1).

Não restam dúvidas de que a obra consegue revelar-se realista o bastante para convencer, até os leitores mais céticos, de que o âmbito criado em suas páginas tem um funcionamento estável e normal; que é um "mundo absolutamente crível" e onde "parece impossível que qualquer coisa impossível possa acontecer" (ROAS, 2014, p. 167). O próximo passo do fantástico é inserir na narrativa o elemento desconhecido, que não se encaixe dentro desta realidade construída pela obra, gerando assim um conflito. Essa é a razão básica do fantástico: "revelar algo que vai transtornar nossa concepção de realidade" (ROAS, 2014, p. 114), ou seja, o sobrenatural.

Em Esfinge, o sobrenatural apresenta-se por meio do personagem protagonista James Marian. Como dito anteriormente, o jovem inglês tinha comportamento e aparência incomuns. Por causa desse fato, ele se tornou o assunto principal das conversas dos outros moradores da pensão. Certa vez, em um almoço de domingo, Basílio, Bernaz e Brandt discutem por sua causa e Miss Barkley, para dar fim ao diálogo acalorado, sentencia: "Esqueçam mister James com suas excentricidades" (NETO, 1925, p. 18).

Torna-se interessante mencionar que entre os muitos adjetivos conferidos a James Marian, "excêntrico" é aquele utilizado com mais frequência. Nas páginas iniciais ele aparece três vezes: "o formoso e excêntrico", "Lá vai o excêntrico, disse o músico" e "já vês que o inglês não é tão excêntrico quanto parece" (NETO, 1925, p. 12-25). Essa palavra torna-se muito sugestiva neste contexto, pois de acordo com Ferreira (2010), excêntrico é o "que se desvia ou afasta-se do centro" (p. 328) e o sobrenatural é tudo o que se desvia de um padrão, neste caso, do natural.

O primeiro acontecimento que veio para desestabilizar o sistema estável do leitor, para questionar a "hierarquia culturalizada entre o real e o irreal" (CHIAMPI, 2015, p. 56) ocorreu em uma noite em que o narrador-personagem estava se preparando para dormir. Antes de subir para seus aposentos, ele conversou com alguns amigos e também inquilinos da pensão, momento em que soube da ausência de James: "Estamos livres do inglês por algum tempo. 
Escreveu a Miss Barkley pedindo umas coisas. Está na Tijuca, com o Smith. Que fique por lá o mais que puder" (NETO, 1925, p. 82).

Nesta mesma noite, a pensão entrou em alvoroço com a doença repentina da professora Miss Fanny. Já em seu quarto, o narrador foi tirado de sua tranquilidade com a notícia: "Estávamos à varanda quando ela apareceu tossindo aos arrancos, ansiada ... Agarrou-se a uma coluna, e, quando vimos, foi a golfada de sangue, para mais de um litro, sei lá" (NETO, 1925, p. 84). Após este momento de tensão, a pensão reencontrou o silêncio natural de sempre. Ao retornar para seu aposento, a fim de descansar, o narrador-personagem deparouse com a seguinte visão:

\footnotetext{
Um raio de luz branqueou o soalho, quebrou-se na barra da parede (...) E do soalho foi-se levantando em alvura, crescendo, tomando forma na sombra.

Fez-se um vulto esbelto e, sob a ampla túnica que o envolvia, desenhavam-se contornos femininos. Alvo, como de gesso, rígido, em atitude lapidar, prendia-me os olhos e, acentuando-se-lhe os traços do rosto, neles reconheci as feições de James.

Os braços nus saiam-lhe das dobras moles da túnica, brancos, estendendo-me as mãos brancas. Era James Marian e, naquele traje, seu rosto realçava mais belo. Era ele, como eu imaginara em devaneio (NETO, 1925, p. 85).
}

Diante de tal acontecimento, a reação do narrador-personagem foi a de temor: "(...) deixei-me cair no divã, opresso, com a respiração em angústia, estrangulado de medo" (NETO, 1925, p. 86). Mas por que isso ocorreu? Todo o aspecto de James Marian possivelmente fez o narrador-personagem pensar que estava diante de um fantasma, que é um ser sobrenatural por ser uma transgressão tanto das leis físicas que organizam o nosso mundo (pois fadado a viver eternamente, não sofre a com a ação do tempo, além de ser destituído de matéria) quanto da noção empírica do mundo real que, segundo Vax, é formada por alguns conceitos correntes das leis de causalidade, de tempo e de espaço. Entre eles estão:

(...) os rios não invertem seu curso, os desejos não se realizam à sua simples formulação, os mortos não voltam para atormentar os vivos, as paredes não se deixam atravessar, não se pode estar em dois lugares ao mesmo tempo etc (apud CHIAMPI, 2015, p. 54- grifo nosso). 
Esses conceitos faziam parte da consciência do narrador-personagem, tanto que, no dia seguinte, ele tentou encontrar explicações para o acontecimento ocorrido anteriormente, uma vez que este ia de encontro a tudo o que ele acreditava até então:

Levantei-me, saí ao corredor querendo ver o ponto em que me aparecera a visão. Examinei atentamente o soalho, as paredes, o teto como à procura duma fresta por onde houvesse passado o corpo fluido que surgira ante $\mathrm{mim}$, em atitude de estátua, tomando-me o passo. E ali esqueci-me, com espírito perdido, o olhar inerte, parado na contemplação airada do inexistente (NETO, 1925, p. 94-5).

Embora assustado, não encontrando uma explicação racional para o que imaginava ter visto, o narrador-personagem decide esquecer o fato e aceitar que tudo não passou de uma ilusão de ótica. No entanto, dias depois, ele ouve de seus amigos que Miss Fanny, em um momento de alucinações, afirmava ter visto James Marian à cabeceira de sua cama na mesma noite em que ele teve sua visão. O mais intrigante é que a descrição da enferma correspondia, exatamente, à dele.E se não bastasse, Brandt, o músico, confessou tê-lo visto na mesma noite com os mesmos trajes.

E agora? O que Miss Fanny teve foi mesmo uma alucinação em decorrência de sua enfermidade? Mas se os dois homens estavam lúcidos, e de fato era James Marian, como poderia sê-lo, se era sabido de todos que ele estava com o Smith noutro bairro da cidade? O leitor é posto na desconfortável posição de dúvida, na indecisão entre qual opção escolher. Este choque entre as duas possibilidades é essencial à narrativa, pois o fantástico é esta "hesitação experimentada por um ser que só conhece as leis naturais, face a um acontecimento aparentemente sobrenatural" (TODOROV, 1975, p. 31).

Sem explicações científicas, as personagens entram em considerações filosóficas para reestabelecer a ordem do cosmo. Em seguida, a atenção do leitor é roubada para a morte de Miss Fanny e outros acontecimentos naturais e comuns da vida, na intenção de que o mundo seja reordenado e a pequena ruptura na concepção de real, tanto do narrador quanto do leitor, seja restaurada: 
A vizinhança apinhava-se às janelas; havia curiosos pelas calçadas. Miss Barkley esperou que se afivelasse a última correia e, quando o féretro moveu-se, fez um aceno tão simples com a mão como se se despedisse, por horas ligeiras, da que ia para a Noite sem alvorada ou para a manhã radiosa do Dia que não finda (NETO, 1925, p. 137).

Pouco tempo depois, já esquecido dos fatos sobrenaturais, o narradorpersonagem mostra-se totalmente recuperado e envolvido em suas atividades cotidianas. Numa tarde qualquer, enquanto fumava um cigarro, fica a observar crianças barulhentas brincando na rua; depois, ouve um grande estrondo: "Era uma banda militar que passava a bonde para o Botafogo" (NETO, 1925, p. 180). Em seguida,toca a campainha na sala, anunciando a hora do jantar. À varanda, alguns dos hóspedes, entre risos, conversam sobre assuntos de pouca importância:

\begin{abstract}
O assunto era um telegrama de Péricles, exaltado em patriotismo, com a gravata a esvoaçar em pontas soltas, estrondava hipérboles rememorando nossa história épica: batalhas renhidas, feitos de bravura, atos de temeridade e gabava, com desabalados gestos, a resistência e a valentia sem arrogância do caboclo do Norte e o arranque desabrido dos cavalarianos do Sul (...) (NETO, 1925, p. 182).
\end{abstract}

A vida logo volta ao seu fluxo rotineiro: "o céu mantém sua 'igual limpidez', as ruas o seu habitual 'hormigueo popular'” (CHIAMPI, 2015, p. 57). Mais uma vez, por meio do narrador-personagem, o leitor sente que o universo textual, à semelhança do mundo extratextual, é um lugar seguro. Um lugar livre de ameaças de monstros, fantasmas e quaisquer coisas de natureza desconhecida. Este retorno à ordem primeira dos acontecimentos, trazendo à pensão Barkley os ares pacíficos do início da narrativa, fez-se extremamente necessário. Reerguendo e sustentando o realismo, antes fragilizado, o autor desarma o leitor e "assegura o efeito chocante que 0 insólito provoca num universo reconhecível, familiar e estruturado" (CHIAMPI, 2015, p. 57).

James Marian voltou a ser motivo de conversa entre os moradores da pensão. Propositalmente, o narrador-personagem concede uma informação ao leitor que, a princípio, parece ser uma notícia gratuita, sem valor, mas que é muito útil para o desenrolar da narrativa: 
(...) Como vai o Apolo de bretão? O formoso James, assombro e maravilha da cidade?

-- Meteu-se na Tijuca a caçar borboletas, disse o comendador.

-- Não tem aparecido?

-- Não.

-- Homem estranho.

(...) Miss Barkley falou:

-- Acho que ele está a partir.

-- Deixa-nos?

-- Sim. Volta para a Inglaterra.

-- Por quê?

-- É um esquisito? (NETO, 1925, p. 188).

Através do excerto acima, algumas informações fixam-se na mente do leitor: 1. Desde que foi para a Tijuca, James não mais apareceu, ou seja, ele NÃO ESTÁ na pensão Barkley. 2. James está prestes a partir de uma vez por todas do Rio de Janeiro. Ele vai para a Inglaterra. 3. James é estranho e esquisito. Em posse de tais notícias, o leitor prossegue pela narrativa despreocupadamente e depara-se com mais outro diálogo sobre o inglês. Dessa vez, o narradorpersonagem conversa com um amigo sobre um livro que James Marian havia deixado para que ele o traduzisse.

O livro estava repleto de elementos sobrenaturais que o narrador acreditava ser a própria biografia do inglês. Seu interlocutor, Décio, não acreditando em suas palavras, rompeu em gargalhadas: "Vai, vai buscar homem da Fantasia, enquanto preparo o espírito do maestro, que está como o furibundo Ajax, para ouvir-te e gosar" (NETO, 1925, p. 194). Não querendo passar por mentiroso, o narrador deixou o amigo por alguns instantes e foi em busca do livro misterioso que estava em seus aposentos. Já com o manuscrito em mãos, o narrador preparava-se para sair e mostrá-lo ao amigo quando entra pela porta James Marian:

(...) o inglês parecia de mármore - olhos parados, sem o mais ligeiro friso na face branca e impassível, imóvel e hirto (...). Falou em tom pausado e as palavras morriam antes da última sílaba como se the faltasse alento para completá-las (NETO, 1925, p. 197).

O inglês foi buscar seu livro e a tradução. Conversaram pouco. O aspecto fisionômico do jovem era mórbido e fantasmagórico. James Marian não se demorou. Agora, sem o livro, como provaria a Décio que estava falando a 
verdade? O narrador tranquilizou-se com a certeza de que o inglês não sairia da pensão sem ser visto ou sem conversar com Miss Barkley, de quem era próximo. Para o fim da narrativa, o fato mais extraordinário: momentos depois, o narrador homodiegético ouviu dos lábios de Brandt que, há dois dias, o inglês havia retornado para a Europa, portanto, o encontro entre os dois seria impossível:

\footnotetext{
- Partida?

- Sim, no Avon, anteontem. Num arrancado ímpeto pus-me de pé hirto, eletrizado, sentindo um como repuxamento em todos os nervos. A voz saiu-me silvante, áspera, articulando a custo as palavras: - Partiu! Como? Não é possível.

[...] - Digo-te, afirmo-te que não é possível. James esteve comigo há coisa de um quarto de hora, lá em cima. Veio buscar o volume que me emprestou e os originais que traduzi. Falei-lhe, acompanhei-o à escada... (NETO, 1925, p. 204-5).
}

Este acontecimento foi um golpe violento à noção empírica de mundo real do narrador-personagem. Ele viu James. No entanto, todos, em uma só voz, afirmavam que James tinha partido há dois dias para a Inglaterra. Então ele estava em dois lugares ao mesmo tempo? Ele era um fantasma? O narradorpersonagem afirmou veementemente: "Não! Não é possível! Insisti. É troça" (NETO, 1925, p. 205). Não é possível segundo as leis da natureza. De acordo com essas leis, fantasmas não existem. O narrador debateu-se em agonia: "Chorei. As lágrimas rolavam-me dos olhos grossas e silenciosas" (NETO, 1925, p. 212). Não podia ser, mas era.

\section{CONCLUSÃO:}

Diante da análise realizada, entende-se que, na construção de seu espaço ficcional, o gênero fantástico depende tanto do "efeito de real" quanto as narrativas miméticas, sendo unânime entre os teóricos "o reconhecimento das convenções do realismo romanesco como necessárias à fantasticidade" (CHIAMPI, 2015, p. 57). Segundo Roas (2014), o realismo no fantástico veio como resposta à exigência de tornar críveis os acontecimentos extraordinários aos leitores cada vez mais atentos e céticos. 
Conhecedores das convenções formais e temáticas do gênero, os leitores não mais se deixavam surpreender com certa facilidade, tornando urgente ao fantástico uma nova roupagem. Assim, mesmo parecendo contraditório, o fantástico, gênero que lida com o sobrenatural, precisou aproximá-lo o quanto possível do mundo real e natural. No romance Esfinge, de Coelho Neto, o conflito entre as duas realidades co-presentes, real versus sobrenatural, promoveu a hesitação que, na teoria todoroviana é a essência do fantástico. O choque trouxe também perplexidade e medo ao narrador-personagem, característica que Lovecraft (2007) apresenta como sendo a marca definidora do gênero.

Além das características apresentadas, é evidente que a irrupção do sobrenatural promoveu, antes de tudo, a desestabilização do real-ficcional que é construído a partir da "ilusão de referencialidade ao mundo extratextual". Para o narrador-personagem, o segundo encontro com 0 inglês não podia ser considerado uma ilusão óptica, como o primeiro. Ele tinha certeza da veracidade daquele instante, embora não conseguisse explicar. Tal proximidade entre os dois mundos, real e ficcional, leva o leitor a questionar também a própria realidade em que ele está inserido. Isso não é ruim. A literatura tem esse poder: o de promover o desconforto. Este é o primeiro passo para a mudança.

\title{
"EFECT OF REAL " VERSUS SUPERNATURAL: A CONFLICT NECESSARY TO THE CONSTRUCTION OF FANTASTICITY IN ESFINGE, BY COELHO NETO
}

\begin{abstract}
According to Roland Barthes (1971), the notion of the effect of real is essential for the realist texts, this way we intend to understand how the narrative Esfinge, by Coelho Neto, uses strategies of descriptions of the extratextual world, gradually Inserting supernatural facts, construct what can be called the fantasticity of the work. Thus, we argue that the construction of the fantastic in the work under analysis is tied to the way the narrative uses the references of the real world and how they, by opposing the fantastic facts of the work, impose on the reader the solution of a doubt. The research follows the theoretical directions of Tzvetan Todorov (1975), Antonio Compagnon (2010), David Roas (2014) and Irlemar Chiampi (2015).
\end{abstract}

KEYWORDS: Fantastic literature. Effect of Reality. Supernatural. Coelho Neto

\section{REFERÊNCIAS:}

ADORNO, Theodor W. Posição do narrador no romance contemporâneo. In: Notas de Literatura I. São Paulo: Duas Cidades; Ed. 34, 2003. 
BARTHES, R. Efeito de real. In: Literatura e semiologia. Petrópolis: Vozes, 1971.

CHIAMPI, Irlemar. O realismo maravilhoso: forma e ideologia no romance hispano-americano. São Paulo: Perspectiva, 2015.

COMPAGNON, Antoine. O mundo. In: 0 demônio da Teoria: literatura e senso comum. 2ed. Belo Horizonte: Editora UFMG, 2010.

FERREIRA, Aurélio Buarque de Holanda. Mini Aurélio: o dicionário da língua portuguesa. 8.ed. rev. atual. Curitiba: Positivo, 2010.

LOVECRAFT, H.P. O Horror Sobrenatural em Literatura. São Paulo: lluminuras, 2007.

NETO, Coelho. Esfinge. 3. ed. Porto: Hillaud e Bertrand, 1925.

TODOROV, Tzvetan. Introdução à Literatura Fantástica. São Paulo: Editora Perspectiva, 1975.

ROAS, David. A ameaça do fantástico: aproximações teóricas. São Paulo: Editora Unesp, 2014.

RODRIGUES, Selma Calasans. O Fantástico. São Paulo: Editora Ática, 1988.

Data de Submissão: 27/03/17

Data de Aprovação: 06/05/17 